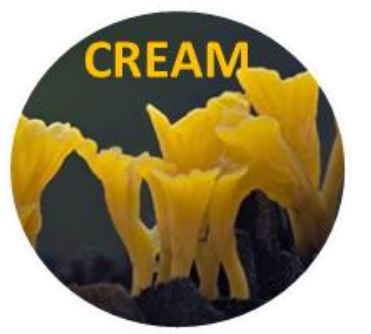

Current Research in Environmental \& Applied Mycology 6 (3): 197-201(2016) ISSN 2229-2225

www.creamjournal.org

Article

CREAM

Copyright $@ 2016$

Doi 10.5943/cream/6/3/7

\title{
Colemaniella biligiriense sp. nov. - A new hyphomycetous fungus from Western Ghats of India
}

\section{Sengupta $\mathbf{S}^{\mathbf{I}}$ and Dubey $\mathbf{R}^{\mathbf{1}}$}

\author{
Botanical Survey of India, Western Regional Centre, Pune
}

Sengupta S, Dubey R 2016 - Colemaniella biligiriense sp. nov. - A new hyphomycetous fungus from Western Ghats of India. Current Research in Environmental \& Applied Mycology 6(3), 197-201, Doi $10.5943 /$ cream/6/3/7

\begin{abstract}
An undescribed hyphomycetous fungus was collected during investigations of microfungi on dead leaf materials in Terminalia bellarica (Gaertn.) Roxb. In morphology, new collection resembles Colemaniella which is monotypic. New collection was compared with type species and it is morphologically distinct thus introduced as Colemaniella bilgiriense. New species is illustrated, description is provided and compare with the type species.
\end{abstract}

Key words - Biodiversity - microfungi - morphology - taxonomy.

\section{Introduction}

Biligiri Rangaswamy Temple Wildlife Sanctuary (BRT WLS), Karnataka is located between $11^{\circ} 40^{\prime}-12^{\circ} 09^{\prime} \mathrm{N}$ lat. and $77^{\circ} 05^{\prime}-77^{\circ} 15^{\prime} \mathrm{E}$ long. With an area of approximately $540 \mathrm{~km}^{2}$ and five forest administrative ranges, the sanctuary presently is a part of the Chamarajanagar district of Karnataka. The sanctuary is the live bridge between Eastern and Western Ghats. The forests of the sanctuary have been classified as evergreen forest (EF $-10.3 \%$, which includes evergreen, shola and high altitude grassland), moist deciduous forest (MDF - 25\%), dry deciduous forest (DDF - 36.1\%) and scrub forest (SF - 28.2\%) (Kumara et al. 2012). During mycological survey of conidial fungi from the moist deciduous forest of Biligiri Rangaswamy Temple Wildlife sanctuary, an unusual and very interesting hyphomycetous fungus was collected from the dried leaves of Terminalia bellarica (Gaertn.) Roxb. The fungus was identified as a species of Colemaniella based on the presence of cyathiform conidiophores. Colemaniella is a monotypic genus with its type species i.e. Colemaniella ossoorii Agnihothrudu (Jamaluddin, 2004, Annonymous 1974 - 2016, Bilgrami et al. 1981, 1991 ) distinctly characterised by monotretic, cyathiform, striated conidiogenous cells and broadly, striated, muriform, dark brown conidia having hyaline basal cells, which protrude as short corniform structures. The present species shows significant difference from the type species in having conidia equally partitioned into two halves prominently by long dark brown septa in the middle forming a single unit. Thus, new collection is introduced as a new species based on morphology. 


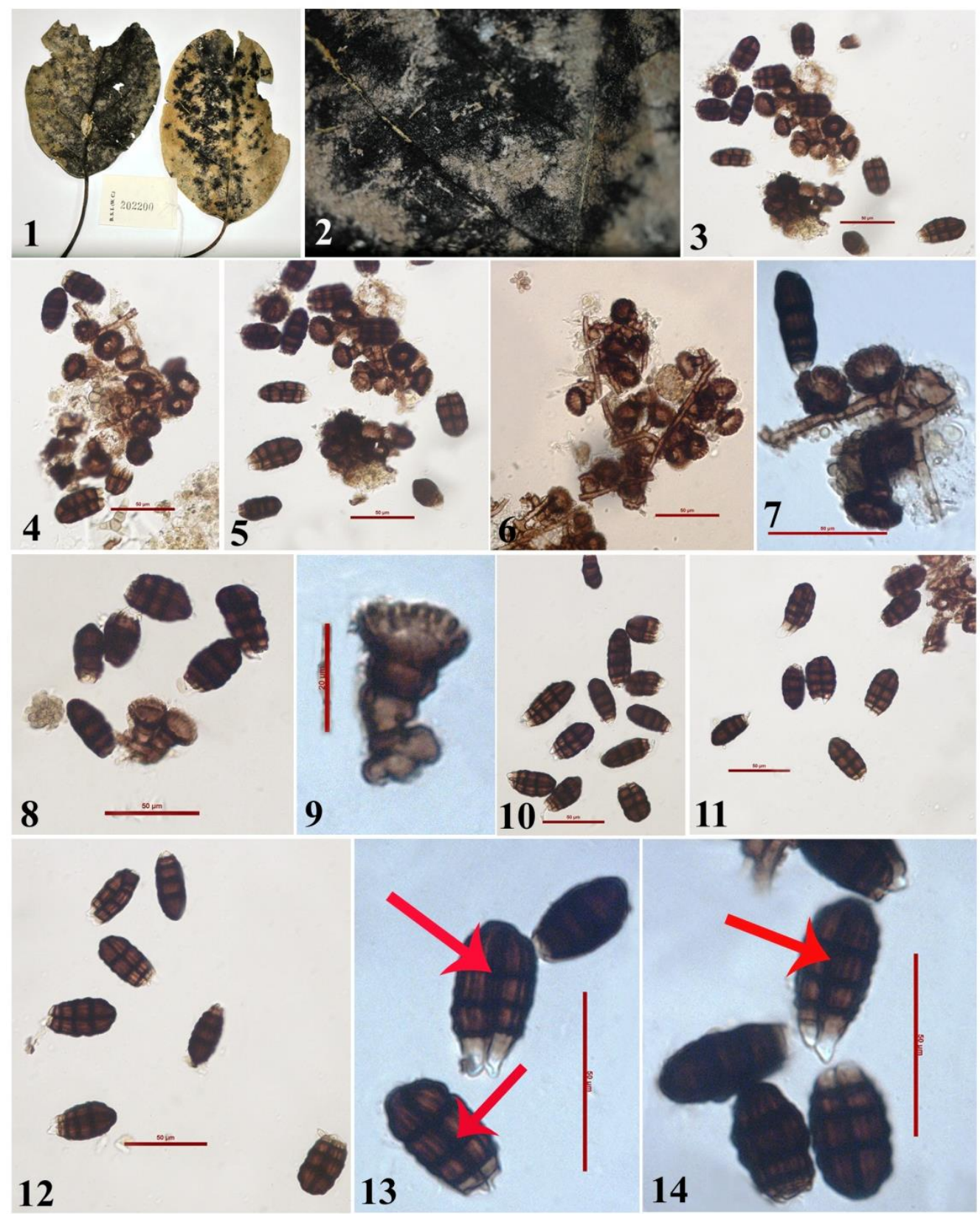

Figs. 1-14 - Colemaniella biligiriense sp. nov. - 1 Infected leaves of Terminalia bellarica (Gaertn.) Roxb. 2 Velvety, black colonies of $C$. biligiriense sp. nov. $3-8$ Colonies showing cyathiform conidiogenous cell and conidia. 9 Enlarged view of cyathiform conidiogenous cell. 10 - 12 Conidia. 13 - 14 Muriform conidia showing two equal halves separated by dark brown septum at the middle. Bars 3 -8 and $10-14=50 \mu \mathrm{m}, 9=20 \mu \mathrm{m}$.

\section{Materials and Methods}

\section{Isolates and Morphology}

Samples of dried leaves were placed in brown paper bags, taken to the laboratory, and prepared according to Castañeda-Ruiz (2005). Mounts were prepared in PVL (polyvinyl alcohol, lactic acid, and phenol). Photomicrographs were taken using a Nikon eclipse 50 i microscope connected to a Nikon DS- Fi 1 camera. Scanning electron microscopic images were captured using Zeiss scanning electron microscope (Model EVO 18-12-97). The type specimen is deposited in Botanical Survey of India, Western Regional Centre, Pune. 

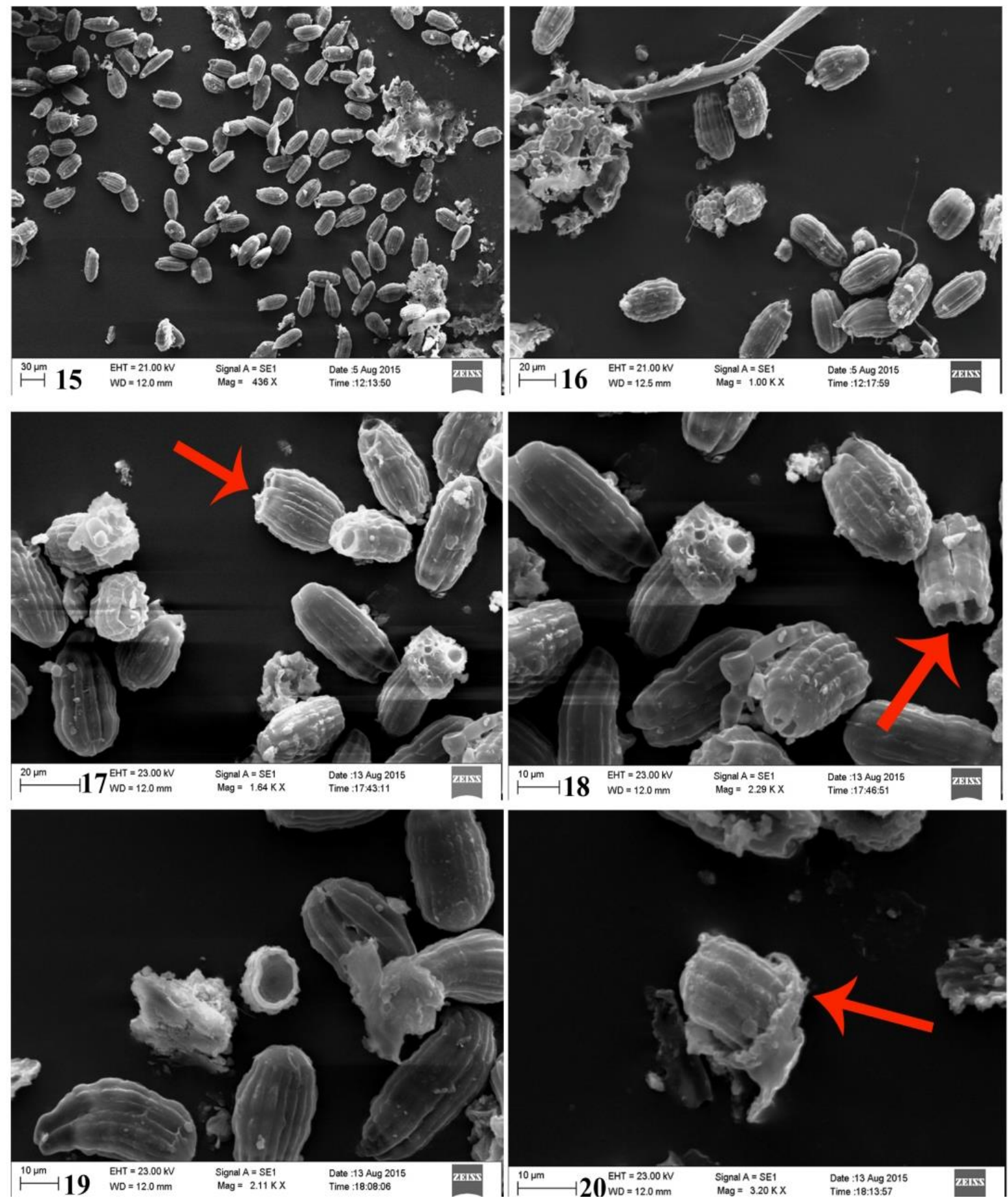

Figs 15-20 - Scanning electron microscopic images of Colemaniella biligiriense sp. nov. - 15-16 Colonies of $C$. biligiriense sp. nov. showing numerous conidia 17 - 19 Muriform conidia showing two equal halves 20 Cyathiform conidiogenous cell.

Colemaniella biligiriense Dubey and Sengupta, sp. nov

Figs 1-20

Mycobank: MB815473

Facesoffungi number: FoF 02523

Etymology - species named after the place of collection (Biligiri Rangaswamy Temple Wildlife Sanctuary, Karnataka, India).

Colonies effuse, black, hard velvety, mycelium superficial, brown, reticulate. Stroma none. Setae absent. Hyphopodia rarely reported, 10-12 × 6-8 $\mu \mathrm{m}$. Conidiophores micronematous or semi macronematous. Conidiogenous cells are discrete or integrated on short branches and monotretic, 
cyathiform and striate, mid to dark brown, 13-16 $\mu \mathrm{m}$ long, 6-11.5 $\mu \mathrm{m}$ thick at the base, and 22-28 $\mu \mathrm{m}$ thick at the apex. Conidia solitary, dry, straight, split into two halves prominently by a long dark brown septa in the middle, muriform, ellipsoidal with striate walls, dark brown except for the basal cells which often remain hyaline or pale and may protrude as a short corniform structure, $29-45 \times 16-22 \mu \mathrm{m}$ (mean $=40.66, \mathrm{n}=16)$.

Teleomorph - unknown.

Known Distribution - Biligiri Rangaswamy Temple Wildlife Sanctuary, Karnataka, India.

Material examined - India, Karnataka, Biligiri Rangaswamy Temple Wildlife Sanctuary, on dried leaves of Terminalia bellarica (Gaertn.) Roxb. (Holotype), 26 March 2015, Shreya Sengupta, Accession No. BSI (WC) 134488.

Notes - Second time reported from Karnataka state of India.

\section{Key to the species}

Conidia straight or slightly curved, muriform, broadly ellipsoidal or obovoid with striate walls, basal cell often remain hyaline or pale, $24-50 \times 16-25 \mu \mathrm{m}$ .C. ossoorii.

Conidia solitary, dry, muriform, ellipsoidal, split into two equal halves by a dark brown septa in the middle, basal cell often remain hyaline, $29-45 \times 16-22 \mu \mathrm{m}$. C. biligiriense.

\section{Discussion}

On comparison of the present taxon with allied genera viz. Bahugada Reddy and Rao 1984 , Oncopodiella Arnaud and Rifai1965 and Monodictys Hughes 1958, It was found completely distinct as the conidiogenous cells of Bahugada are denticulate and terminal along with pyriform and obovate conidia with a cyathiform basal hyaline cell separated from the longitudinally and transversely septate portion of the conidium. Similarly in case of Oncopodiella the conidiogenous cells are cylindrical, denticulate and conidia are corniculate, dry, trigonous, pyriform, muriform, with a protuberant hilum, along with it also possess $2-4$ short conical hyaline horns; whereas in the Monodictys the conidiogenous cells are determinate, cylindrical, doliform or sub - spherical and conidia are simple, oblong, rounded at the ends, with varied shapes, sometimes may be spirally twisted.

While in Colemaniella the conidiogenous cells are discrete, integrated, cyathiform, striate, monotretic, mid to dark brown and conidia is solitary, broadly ellipsoidal or obovoid, muriform, dark brown to blackish brown except the basal cells which often remain hyaline or pale, may protrude as short corniform structures. Thus the unique feature assigns the new taxon in genus Colemaniella. Although the present species differs from the type species $C$. ossoorii in having muriform conidia which possess dark brown middle septum, thus dividing the conidia into two equal halves.

\section{Acknowledgements}

Author is thankful to the Dr.Paramjit Singh, Director, Botanical survey of India, for his kind support and providing all the research facilities. They are also grateful to the Head of the office, Botanical Survey of India, Western Regional Centre, Pune, for his kind support and encouragement. Forest Department of Karnataka is thankfully acknowledged for their support. Ministry of Environment and Forest, New Delhi, is thankfully acknowledged for financial assistance.

\section{References}

Anonymous. 1974-2016 - Fungal Database Nomenclature and species identification. MycoBank. http://www.mycobank.org/Colemaniella (Accessed on 01.06.2016).

Bilgrami KS, Jamaluddin, Rizwi MA. 1979 - The Fungi of India. Part I (List and References). Today and Tomorrow's Printers and Publishers, New Delhi. 467.

Bilgrami KS, Jamaluddin, Rizwi MA. 1981 - The Fungi of India. Part II (Host Index and Addenda). Today and Tomorrow's Printer and Publishers. New Delhi. 128. 
Bilgrami KS, Jamaluddin, Rizwi MA. 1991 - The Fungi of India. Part III (List and References ). Today and Tomorrow's Printer and Publishers, New Delhi. 798.

Castañeda-Ruiz RF. 2005 - Metodologíaen el estudio de loshongosanamorfos. 182- 183, in: Anais do V Congresso Latino Americano de Micología. Brasilia.

Ellis MB 1976 - More Dematiaceous Hyphomycetes. C.A.B. Commonwealth Mycological Institute, Kew, Surrey, England. 507p.

Hughes SJ. 1958 - Revisiones Hyphomycetum aliquot cum appendice de nominibus rejiciendis. Canadian Journal of Botany. 36(6),727-836.

Jamaluddin, Goswami MG, Ojha BM. 2004 - Fungi of India, (1989 - 2001). Scientific Publishers India, Jodhpur. 329 pp.

Kumara HN, Rathnakumar S, Sasi R, Singh M. 2012 - Conservation status of wild mammals in Biligiri Rangaswamy Temple wildlife sanctuary, the Western Ghats, India. Current Science. 103, 933940.

Maheswari CU, Sharma RK, Kamil D, Devi JP. 2012 - Herbarium Cryptogamae Indiae Orientalis, Catalogue of Fungal Specimens. Vol. 1. Division of Plant Pathology, Indian Agricultural Research Institute, New Delhi.100pp.

Reddy KA, Rao VG. 1984 - A new hypomycetes. Current Science 53 (10), 542-544.

Rifai MA. 1965 - On Sporidesmium trigonellum Sacc. Persoonia. 3(4), 407-411. 